Bond University

Research Repository

\title{
Effectiveness of sensory modulation in treating sensory modulation disorders in adults with schizophrenia: a Systematic Literature Review
}

Machingura, Tawanda; Shum, David; Molineux, Matthew; Lloyd, Chris

Published in:

International Journal of Mental Health and Addiction

DOI:

10.1007/s11469-017-9807-2

Licence:

Other

Link to output in Bond University research repository.

Recommended citation(APA):

Machingura, T., Shum, D., Molineux, M., \& Lloyd, C. (2018). Effectiveness of sensory modulation in treating sensory modulation disorders in adults with schizophrenia: a Systematic Literature Review. International Journal of Mental Health and Addiction, 16(3), 764-780. https://doi.org/10.1007/s11469-017-9807-2

\section{General rights}

Copyright and moral rights for the publications made accessible in the public portal are retained by the authors and/or other copyright owners and it is a condition of accessing publications that users recognise and abide by the legal requirements associated with these rights.

For more information, or if you believe that this document breaches copyright, please contact the Bond University research repository coordinator. 
Running head: EFFECTIVENESS OF SENSORY MODULATION

Effectiveness of sensory modulation in treating sensory modulation disorders in adults with schizophrenia: A systematic literature review 


\begin{abstract}
Sensory modulation, as a treatment for sensory modulation disorders in adults with psychiatric conditions, has been implemented by occupational therapists for more than two decades. The purpose of this systematic literature review was to evaluate published research evidence relating to this intervention. The aim of the study was to determine if there was established evidence for the effectiveness of sensory modulation in treating sensory modulation disorder in adults with schizophrenia and to identify any gaps in knowledge to guide further research. We utilized Australia’s National Health and Medical Research Council (NHMRC)'s levels of evidence and recommendation grading and the Rosalind Franklin Research Appraisal Instrument (RF-QRA) to review selected articles. The results were then summarized and reported utilizing the Preferred Reporting Items for Systematic Reviews and Meta-Analyses (PRISMA) framework. A total of 17 studies were included in the study. We concluded that there is preliminary evidence for the existence of sensory modulation disorder in schizophrenia and the effectiveness of sensory modulation interventions for reducing distress. We recommended further studies on the effectiveness of sensory modulation with better rigor and advise that guidelines be developed for use in practice by clinicians.

Keywords: Sensory modulation; sensory approaches; occupational therapy and schizophrenia
\end{abstract}


Effectiveness of sensory modulation in treating sensory modulation disorders in adults with schizophrenia: A systematic literature review

Schizophrenia is a debilitating condition that is as old as humankind and has a chronic

and unremitting course affecting a person's well-being and participation in daily activities (Green, Kern, Braff, and Mintz, 2000). Major criterion for the diagnosis of schizophrenia includes the presence of hallucinations, delusions, disorganized thinking (speech), grossly disorganized or abnormal motor behavior (including catatonia), and negative symptoms among other symptoms (American Psychiatric Association, 2015). Current treatment of schizophrenia may reduce symptoms of the condition however it remains complex and at times ineffective with antipsychotics having serious and sometimes lethal side effects (Kurtz, 2005). World-wide there is increasing demands for consumer centered humane approaches for people with schizophrenia or other mental illnesses. Sensory modulation is largely regarded as the profession of occupational therapy’s response to that demand (Champagne, 2004, 2011, 2012).

SM is the regulation and organization of the degree, intensity and nature of one's responses to sensory input in a graded and adaptive manner (Champagne, 2010, 2011 \& Lipskaya-Velikovsky, Bar-Shalita and Bart, 2015). SM is an emerging approach in mental health spearheaded by new approaches such as the recovery approach, trauma informed care and seclusion and restraint reduction (Champagne, 2011). SM is an adaptation of sensory integration, an approach used in occupational therapy practice particularly with children (Ayres, 1972 \& Champagne, 2011). SM is argued to facilitate effective participation in occupations as it enables the processing of sensory information and allows individuals to then generate an appropriate behavioral response. Sensory modulation interventions include activities or modalities which are 
designed to give specific types and amounts of sensation, at specific times, for therapeutic purposes (Champagne, Koomar, and Olson, 2010). SM targets all seven senses: visual, auditory, tactile, gustatory, olfactory, proprioceptive and vestibular systems (Brown, and Stoffel, 2011 \& Champagne, 2011).

Sensory Modulation Disorder (SMD) is a sub-category of sensory processing disorder (SPD), where individuals perceive everyday sensory stimuli as unpleasant and is associated with functional limitations (Bar-Shalita et al., 2012; Javitt, 2009 \& Olson, 2010). SMD can interfere with occupational performance and engagement (Champagne, Koomar and Olson, 2010). This occurs because of difficulties in regulating and organizing the type and intensity of behavioural responses to sensory input to match environmental demands (Miller et al, 2004). Adults with SMD over-respond or under-respond or have fluctuating responses to sensory stimuli to an extent that their participation and engagement in daily occupations is impaired (Bar-Shalita et al., 2012; Champagne et al, 2010 \& Miller et al, 2004). Occupational therapists are interested in addressing SMD since they are concerned with enhancing occupational performance and engagement.

There is preliminary evidence that patients with schizophrenia have sensory modulation disorder. Electrophysiological studies conducted on individuals with schizophrenia support the presence of impairments at the central nervous system level, that affect an individual's ability to effectively interpret and organize sensory input (Bar-Shalita et al., 2012). Bar-Shalita et al., (2012), concluded that the CNS rather than peripheral somatosensory system is the site of the pathophysiology underlying SMD. Adults with SMD show behavioural responses that are inconsistent with available sensory stimuli (Olson, 2010). Several instruments have been 
developed by occupational therapists to diagnose SMD mostly in children. Instruments developed for the adult population include; the Adult Sensory Questionnaire, (Kinneally \& Oliver, 2002), Adult Sensory Interview (Kinnealey, Oliver, \& Wilbarger, 1995) and Adolescent/Adult Sensory Profile (A/ASP), (Brown \& Dunn, 2002). Most of these instruments have remained largely untested (Olson, 2010). The two most widely tested tools used to identify SMD are; the A/ASP (Brown et al., 2002) and the sensory responsiveness questionnaire (SRQ). The SRQ isbased on the work by Bar- Shalita et al, (2012) whilst the A/ASP is theoretically based on Dunn (1997)’s Model of Sensory Processing.

Theorists within the field of occupational therapy currently rely upon Jean Ayres (1972, 1979) sensory integration theory. The use and application of Ayres sensory integration theory in mental health has grown exponentially since the 1970s and has been further modified and expanded by occupational therapists (Champagne \& Stromberg, 2004; Champagne, 2010, 2011, Champagne \& Koomar, 2012; Dunn, 1997; Dunn \& Brown, 1997). A major advancement of Ayres theory was made by Dunn (1997) who proposed that four sensory processing patterns arising from individual differences in neurological thresholds for stimulation (high-low) and selfregulation strategies (active-passive) characterize the perceptual process. The growth is also to a large extend due to the promise that sensory modulation has shown in addressing initiatives such as reducing the need for seclusion and restraint, and as an intervention that is consistent with the principles of recovery and trauma informed care (Champagne, 2012). This promise together with a lack of other alternatives is likely responsible for the acceptance of SM in mental health with limited scrutiny. There has been very limited published research on the topic despite the widespread uptake of the intervention within occupational therapy. We concluded that a systemic review would ascertain what has been established and help identify areas where research was 
needed.

The specific aims of this review were to examine the literature on the existence of SMD in patients with schizophrenia, and to examine current understanding on the effectiveness of sensory modulation in treating sensory modulation disorder in these patients. A final aim was to identify any gaps in knowledge to guide further research.

\section{Method}

The search strategy included identifying main concepts and keywords, their synonyms and related themes. Search terms used were a combination of subject heading terms and keywords for schizophrenia AND sensory modulation OR sensory approaches. Firstly, articles were identified through database searches, then articles were screened using predetermined criteria for relevance to the topic. Reference lists of studies identified were then inspected for relevant cross references. This process was repeated until no new studies could be found. The databases selected and searched were CINAHL, ProQuest, Google Scholar, Medline, OT Seeker, Science Direct, EBSCO Host, Cochrane, PsychInfo, Embase and PubMed.

The articles abstracts were then read. We were interested in studies that had been peer reviewed and utilised the criteria for inclusion as follows: Published research papers (in English) in the last 40 years (1975 to present). This is because sensory modulation was first used in the mental health area about 40 years ago; principally about sensory modulation or sensory approaches in adults with schizophrenia. Those excluded were either primarily on other domains such as, cognition or were not relevant to adults with schizophrenia or to occupational therapy. The 
types of studies included for analysis was broadened to include qualitative studies because no randomised controlled trials or meta-analyses could be found and only a few experimental studies have been published at the time of the review.

Selected articles were then classified according to research type and evidence level by two of the authors working separately. The authors then met to confirm the agreed level of evidence. The level of evidence for each included study was assessed using two evidence based tools: For quantitative studies, NHMRC - Levels of evidence and recommendation grading was used and for qualitative studies the RF-QRA was used. The reliability and validity of data for each outcome was assessed. The risk of bias within and across studies was also assessed and rated.

\section{Results}

The electronic databases were initially searched in April 2015 and yielded 392 articles.

Review of titles and abstracts of these studies reduced the number of studies to 56 . We then identified an additional 9 studies in the references of these studies. After screening the full texts and removing duplicates we selected 17 studies which were found to be relevant to the topic and to meet the selection criteria. Those excluded were either on other domains e.g. cognition or sensory processing or sensory integration, or were not conducted with adults or did not include people with schizophrenia. 


\section{Characteristics of studies}

Most of the relevant articles were published between 2011 and 2015, (n=12) with only a few relevant studies $(n=5)$ being published prior to this date. Of those that were considered relevant $(n=17)$, most studies were conducted in the USA $(n=9)$, and only a few were conducted in Australia ( $n=3)$ and Israel $(n=3)$ and New Zealand $(n=2)$. Most of the studies were quantitative studies 9 out of 17. At the time of this review there was only one mixed method study conducted on the topic.

\section{[Attach Figure I-Geographical Distribution of Studies]}

The extent of research quality was reflected in the level of evidence and grade of recommendation. We found that of the relevant articles $(n=17)$, study designs were controlled clinical trials or literature reviews/ opinions/ editorials or anecdotal reports. At the time of this review there were no published randomised controlled trials or systematic reviews on the topic. We found that 7 of these relevant articles ( $n=7)$ had a rigor of Grade $C$ or better using Australia's NHRMC scale as shown in figure 1. These articles were by Brown et al (2002); Pfeiffer et al

(2003); Kinnealey et al (2011); Bar-Shalita (2012); Bar-Shalita (2014), and Lloyd et al (2014) as summarised in table 1.

\section{Synthesis of results}

Sensory Modulation Disorder in Schizophrenia. 
Studies conducted on individuals with schizophrenia support the presence of impairments at the central nervous system level, that affect an individual's ability to effectively interpret and organize sensory input (Bar-Shalita et al., 2012). Another study by Brown et al (2002) concluded that adults with schizophrenia demonstrated that they had SMD when compared with adults with Bipolar Affective Disorder. Brown et al., compared patterns of sensory processing disorder in adults with schizophrenia, using the Adolescent/Adult Sensory Profile (A/ASP). In this study individuals with schizophrenia demonstrated increased patterns of sensation avoiding and low registration, and decreased pattern of sensory seeking. Pfeiffer \& Kinnealey (2003), concluded that there was a significant relationship between sensory defensiveness and anxiety and following an intervention designed for adults with SMD both conditions significantly decreased. This finding is significant as evidence for the existence of SMD in schizophrenia as anxiety is often a feature of many psychiatric conditions including schizophrenia.

The results of our systematic review assessed studies by Bar Shalita (2012), Brown et al., (2002) and Pfeiffer \& Kinnealey (2003) as having a grade recommendation of C on the NHMRC scale. We concluded that the results of these studies, that is SMD exists in schizophrenia, were moderately generalizable as the authors had gone to great lengths to minimise bias. The weaknesses were that the authors did not consider symptoms that the participants were experiencing, for example, what was being observed as sensory avoiding could have been negative symptoms of schizophrenia; there was no randomisation of participants and diagnosis of SMD was done solely by self-reports. 
Most studies reviewed generally supported the effectiveness of sensory modulation except the study by Smith and Jones (2014) which found no significant reduction in seclusion rates with the introduction of a seclusion room. Studies on the effectiveness of sensory modulation are few and their results have limited generalizability due to their designs. Studies by Champagne \& Stromberg (2004), Chalmers et al., (2015), Novak et al., (2012), Sutton et al., (2013), and Van Pomeren (2009) concluded that modifications to the environment and the use of soothing stimuli moderates or optimizes arousal and promotes an ability to adaptively regulate emotion. This systematic review however assessed these studies as having a grade recommendation of D or E on the NHMRC scale. Our conclusion was that strength of the evidence for these studies was low and that the likelihood that bias, confounding and/or chance may have influenced these findings was high. The study by Lloyd, King \& Machingura (2014) which had a grade recommendation of C however came to same conclusion as these studies, that is, sensory modulation interventions decrease distress in mental health patients in acute settings. Similarly, to the other studies, their findings advocate for both environmental and cultural changes to achieve better outcomes.

Sensory modulation and occupational engagement and participation.

Lipskaya-Velikovsky et al., (2014), found no significant correlates between participation and SMD unlike in studies on children which found that SMD restricts participation. This study had a few limitations including selection bias as the participants were not randomly allocated to groups. Subjects had chronic schizophrenia with cognitive decline which may have overshadowed SMD. Kinnealey et al., (2011), concluded that sensory style is related to symptoms of affective mental health and quality of life indicators. There were however some 
limitations such as participants not being randomised and the use of a small sample $n=<20$. This study had no control group and used only healthy subjects. We assessed both these studies as having a grade recommendation of level C on the NHMRC scale and concluded that the results were moderately generalizable. This was because of the methodology used, sample size and assessment tools used were relatively valid and reliable.

[Attach table I: Summary of studies with rigor Grade C or better] 


\section{Discussion}

The purpose of this review was to achieve a better understanding of sensory modulation and identify any gaps in knowledge for further research. We found that further studies to examine whether adults with schizophrenia have sensory modulation disorder are much needed.

Diagnosis of SMD needs to be based on symptoms that are quantified by a reliable and valid instrument. The SRQ and A/ASP are both reported in the literature to be reliable and valid selfreports ( Bar-Shalita et al, 2015; Brown, 2001). Bar-Shalita et al (2014) concluded that SRQ is an effective tool for diagnosing SMD as it measures symptoms both in terms of intensity and frequency unlike the A/ASP which only measures frequency. The A/ASP however has been extensively tested in adults with a mental illness with physiological data being consistent with the four quadrants (Brown, 2001; Champagne, 2006). Psychometric properties of the A/ASP include reasonable internal consistency with a coefficient alpha $\alpha=0.60-0.78$ (Brown et al, 2000). Factor analysis supported a four-factor structure with three out of four correlated with intended subscales (Brown et al, 2000). Validity has been established using physiological studies and support for construct validity of the measure has been established (Brown et al., 2001). Although the may be merit in using the SRQ to further test its validity, researchers should continue using the A/ASP which is a validated tool currently available.

Most of the studies we reviewed concluded that sensory modulation interventions decrease distress in mental health patients in acute settings (Chalmers et al., 2015, Champagne \& Stromberg, 2004, Lloyd et al., 2014, Novak et al., 2012, Sutton et al., 2013, and Van Pomeren, 2009). These studies however often used SMP synonymously with SM and the effectiveness of SMPs is therefore often referred to as the effectiveness of sensory modulation (Champagne, 2010, 
2011). We argue that the effectiveness of SMP cannot be inferred from the effectiveness of sensory modulation intervention, as SMPs are a combination of therapies (Champagne, 2010) and their effectiveness may well be due to one or some of the therapies, or all of them in combination. The effectiveness of sensory modulation interventions needs to be further evaluated as individual interventions to reduce bias and as a programme to determine what works and what does not.

The studies we examined were poorly controlled with no clearly defined populations. None of the studies on effectiveness of sensory modulation focused specifically on people with schizophrenia. Only one study focused on the relation between SMD and schizophrenia however it did not take into consideration the phase of schizophrenia. We suggest that further studies should be more controlled and consider variables such as type of schizophrenia; phase of illness; and symptoms (positive, negative or mixed) to improve understanding the influence effectiveness of SM on individuals with these symptoms.

Studies on effectiveness reviewed also had several limitations including that the staff participating in these studies were not blinded and sample sizes were small and there were no controls. These studies also relied heavily only on subjective experience of the patients. Also, all these studies used a non-standardised tool whose validity has not yet been adequately tested. These limitations reduce the external validity of the studies. Also, there is very limited understanding of how effective these interventions are, when are they most effective, which modalities are more effective and for which patients are they effective. This knowledge is vital for practitioners to be able to prescribe, utilise, recommend or guide the patient towards an appropriate and effective intervention. 
The studies conducted and included in this review were from a variety of settings and used different designs which provides evidence of robustness and transferability of results. The issue was that the level of evidence in the research being done is generally low. There is a need for better research designs that can provide higher levels of evidence, such as randomised controlled trials.

\section{Implications for occupational therapy practice}

SM is reported in practice to be generally effective (Dunn, 1997; Lloyd et al, 2014; Champagne, 2004, 2011 \& 2012). Studies substantiating this effectiveness are however still very limited. Furthermore, some researchers have suggested the co-occurrence of SMD and Schizophrenia largely from electrophysiological studies (Bar-Shalita et al., 2012 \& LipskayaVelikovsky et al., 2014). We recommend that;

- Efficacy studies are needed to support the use of sensory modulation with adults with schizophrenia

- Practitioners using sensory modulation should inform their clients of the emerging nature of the evidence

- Researchers further investigate the relationship between SMD and schizophrenia taking into consideration the phase of illness.

\section{Limitations}

This systematic review has some limitations. Firstly, two of the authors included one of their own publications which may have introduced some bias. Secondly the level of evidence in the articles used was generally low for a systematic review. Instead of restricting the review to 
articles with higher levels of evidence only such as randomised controlled trials and metaanalyses, this review included all relevant research articles irrespective of design. Although this approach may not provide definitive answers to questions of effectiveness, it does provide a summary of the current evidence, a baseline from which to move forward. The authors potentially could have been biased to report positively on advances that they are promoting. We minimised the effects of these limitations by utilising evidence based scales to analyse the articles and utilising evidence based reporting framework, PRISMA, to report on our findings (Liberati et al., 2009).

\section{Conclusions}

This review of the literature has established that SM as an intervention is still evolving. Studies examining the effectiveness of SM are limited with most being descriptive studies and not outcome or treatment studies. This review established that there is emerging evidence for a relationship between schizophrenia and SMD however there are still many gaps in knowledge on this relationship. This review has also established that sensory modulation interventions have been subjectively reported as positive however the exact nature of which interventions work best

and when needs further research. We conclude that it is imperative to establish the existence of SMD in the first instance and then test the effectiveness of interventions used to ameliorate SMD. 


\section{References}

American Psychiatric Association. (2015, August 4). psychiatry online. Retrieved from psychiatryonline.org: http://dsm.psychiatryonline.org/store/home.aspx.

Ayres, A. (1972). Sensory Integration and Learning Disorders. Los Angeles: Western Psychological Services.

Ayres, A. (1979). Sensory Integration and the Child. Los Angeles: Western Psychological Services.

Ayres, A. J. (1972). Sensory Integration and Learning Disorders. Los Angeles : Western Psychological Services.

Bar-Shalita, T. V. (2012). Psychophysical correlates in adults with sensory modulation disorder. Disability Rehabilitation 34(11), , 943-950.

Bar-Shalita, T., Vatine, J. J., Parush, S., Deutsch, L., \& Seltzer, Z. (2012). Psychophysical correlates in adults with sensory modulation disorder. Disability Rehabilitation, 34(11), 943-950.

Brown, C. and Stoffel, V.C. (2011). Occupational therapy in mental health: A vision for participation. Philadephia: F.A. Davis Company.

Brown, C., Cromwell, R.L., Fillion, D., Dunn, W., and Tollefson, N. (2002). Sensory processing 
in schizophrenia: missing and avoiding information. . Schizophrenia Research 55(1-2), 187-195.

Chalmers, A., Harrison, S., Mollison, K., Molloy, N., \& Gray, K. (2012). Establishing sensorybased approaches in mental health inpatient care: a multidisciplinary approach. Australasia Psychiatry, 20(1), 35-39.

Champagne, T and Koomar, J. (2012). Evaluating sensory processing in mental health occupational therapy practice. OT Practice 17(5), CE1-CE8.

Champagne, T and Stromberg, N. ( (2004)). Sensory approaches in inpatient psychiatric settings: innovative alternatives to seclusion and restraint. Journal of Psychosocial Nursing \& Mental Health Services 42(9), 34-44.

Champagne, T. (2011). The influence of posttraumatic stress disorder, depression, and sensory processing patterns on occupational engagement: a case study. Work, 38(1), 67-75.

Champagne, T., Koomar, J., and Olson, L. (2010). Sensory processing evaluation and intervention in mental health. OT Practice, 15, CE1-CE9.

Dunn, W. (2007). Living Sensationally. London and Philadelphia: Jessica Kingsley Publishers.

Dunn, W. (1997). The impact of sensory processing abilities on the daily lives of young children and their families: A conceptual model. Infants and Young Children, 9 (4) , 23-35.

Green, M. F., Kern, R. S., Braff, D. L., and Mintz, J. (2000). Neurocognitive deficits and 
functional outcome in schizophrenia: Are we measuring the right stuff? Schizophrenia bulletin, 26 , 119-136.

Javitt, D. C. (2009). Sensory processing in schizophrenia: neither simple nor intact. Schizophrenia Bulletin, 35(6),, 1059-1064.

Kinnealey, M., Koenig, K. P., \& Smith, S. (2011). Relationships Between Sensory Modulation and Social Supports and Health-Related Quality of Life. . American Journal of Occupational Therapy, 65(3), , 320-327.

Kurtz, M. (2005). Neurocognitive impairment across the lifespan in schizophrenia: an update. Schizophrenia Research, 74(1), 15-26.

Lee, S.J., Cox, A., Whitecross, F., Williams, P., \& Hollander, Y. (2010). Sensory assessment and therapy to reduce restraint and seclusion use with service users needing psychiatric intensive care. Journal of Psychiatric Intensive Care, 6(2), 83-90.

Liberati, A., Altman, D. G., Tetzlaff, J., Mulrow, C., Gøtzsche P. C., Ioannidis, J. P., Clarke, M., Devereaux, P. J., Kleijnen, J., Moher D. . (2009). The PRISMA statement for reporting systematic reviews and meta-analyses of studies that evaluate health care interventions: explanation and elaboration. Journal of Clinical Epidemiology, 62(10), e1-e34.

Lipskaya-Velikovsky, L., Bar-Shalita, T., and Bart, O. (2015). Sensory modulation and daily-life participation in people with schizophrenia. Comprehensive Psychiatry, 130-137.

Lloyd, C., King, R \& Machingura, T. (2014). An investigation into the effectiveness of sensory 

Health, 12(2), 93-100.

Novak, T., Scanlan, J., McCaul, D., MacDonald, N., \& Clarke, T. (2012). Pilot study of a sensory room in an acute inpatient psychiatric unit. Australas Psychiatry, 20(5) , 401-406.

Olson, L. M. (2010). Examining schizophrenia and sensory modulation disorder: a review of the literature. Sensory Integration Special Interest Section Quarterly 33(1), 1-3.

Pfeiffer, B and Kinnealey, M. (2003). Treatment of sensory defensiveness in adults. Occupational Therapy International, 10(3), 175-184.

Sutton, D., Wilson, M., Van Kessel, K \& Vanderpyl, J. (2013). Optimising arousal to manage aggression: A pilot study of sensory modulation. International Journal of Mental Health Nursing, 22(6), 500-511. 
Tables

Table I: Summary of studies with rigor Grade C or

better

\begin{tabular}{|c|c|c|c|c|c|c|}
\hline $\begin{array}{l}\text { Year of } \\
\text { Publication }\end{array}$ & Country & Authors & Design & Outcome & LOE & $\begin{array}{l}\text { Grade of } \\
\text { Rec }\end{array}$ \\
\hline 2002 & USA & Brown et al & Quant & $\begin{array}{l}\text { Relationship exists between } \\
\text { SMD and schizophrenia }\end{array}$ & $3(2)$ & $\mathrm{C}$ \\
\hline 2003 & USA & Pfeiffer et al & Quant & $\begin{array}{l}\text { Relationship exists between } \\
\text { sensory defensiveness and } \\
\text { anxiety }\end{array}$ & $3(2)$ & $\mathrm{C}$ \\
\hline 2011 & USA & $\begin{array}{l}\text { Kinnealey et } \\
\text { al }\end{array}$ & Quant & $\begin{array}{l}\text { Relationship exists between } \\
\text { symptoms, sensory style \& QoL. }\end{array}$ & $3(2)$ & $\mathrm{C}$ \\
\hline 2012 & Israel & Bar-Shalita & Quant & SMD occurs at CNS level & $3(1)$ & $\mathrm{C}$ \\
\hline 2014 & Australia & Llyod et al & Quant & SM reduces distress & $3(2)$ & $\mathrm{C}$ \\
\hline 2014 & Israel & $\begin{array}{l}\text { Bar-Shalita } \\
\text { et al }\end{array}$ & Quant & SMD occurs at CNS level & $3(1)$ & B \\
\hline 2014 & Israel & $\begin{array}{l}\text { Lipskaya et } \\
\text { al }\end{array}$ & Quant & $\begin{array}{l}\text { No relationship between } \\
\text { participation and SMD }\end{array}$ & $3(2)$ & $\mathrm{C}$ \\
\hline
\end{tabular}


Table I: Explanation Notes

Table 1 shows that there is preliminary evidence for the existence of sensory modulation disorder in schizophrenia and the effectiveness of sensory modulation interventions for reducing distress. One study did not find a relationship between participation in daily occupations and sensory modulation disorder. 
Table II: Studies included in the systematic review

\begin{tabular}{|c|c|c|c|c|c|c|}
\hline Authors & Title & Design & $\begin{array}{c}\text { Methods/ Participants \& } \\
\text { Interventions }\end{array}$ & Outcomes & $\begin{array}{l}\text { Level of Evidence } \\
\text { (LOE) } \\
\text { Quant- Australia's } \\
\text { National Health and } \\
\text { Medical Research } \\
\text { Council (NHMRC) } \\
\text { Qual- } \\
\begin{array}{l}\text { Rosalind Franklin } \\
\text { Research Appraisal } \\
\text { Instrument }\end{array}\end{array}$ & Limitations/Bias \\
\hline $\begin{array}{l}\text { Lipskaya- } \\
\text { Velikovsky et } \\
\text { al., 2014. } \\
\text { (Israel) }\end{array}$ & $\begin{array}{l}\text { Sensory } \\
\text { modulation } \\
\text { and daily-life } \\
\text { participation } \\
\text { in people } \\
\text { with } \\
\text { schizophreni } \\
\text { a }\end{array}$ & $\begin{array}{l}\text { Observatio } \\
\text { nal study } \\
\text { (case } \\
\text { control } \\
\text { study) }\end{array}$ & $\begin{array}{l}\text { Inpatients with } \\
\text { schizophrenia } n=49 \text { and } \\
\text { health controls } n=32 \\
\text { were assessed for their } \\
\text { participation patterns, } \\
\text { sensory modulation } \\
\text { processes, cognitive } \\
\text { functioning and symptom } \\
\text { severity }\end{array}$ & $\begin{array}{l}\text { No significant } \\
\text { correlates were } \\
\text { found between } \\
\text { participation and } \\
\text { SMD unlike in } \\
\text { studies on } \\
\text { children which } \\
\text { did find that SMD } \\
\text { restricts } \\
\text { participation. }\end{array}$ & $\begin{array}{ll}\text { - } & \text { LOE- 3-2 } \\
\text { - } & \text { Rec Grade-C }\end{array}$ & $\begin{array}{l}\text { Subjects had chronic } \\
\text { schizophrenia with } \\
\text { cognitive decline } \\
\text { which may have } \\
\text { overshadowed SMD. }\end{array}$ \\
\hline $\begin{array}{l}\text { Chalmers s et } \\
\text { al., } 2015 \\
\text { (Australia) }\end{array}$ & $\begin{array}{l}\text { Establishing } \\
\text { sensory based } \\
\text { approaches in } \\
\text { mental health } \\
\text { inpatient } \\
\text { care: a } \\
\text { multidisciplina } \\
\text { ry approach }\end{array}$ & $\begin{array}{l}\text { Pre-and } \\
\text { Post-trial } \\
\text { with no } \\
\text { control }\end{array}$ & $\begin{array}{l}\text { Literature review on } \\
\text { sensory modulation } \\
\text { followed by } \\
\text { implementation of } \\
\text { sensory approaches trial } \\
\text { in an inpatient unit and } \\
\text { quantitative evaluation } \\
\text { after } 3 \text { years. }\end{array}$ & $\begin{array}{l}\text { Reduction in } \\
\text { distress for } \\
\text { consumers using } \\
\text { sensory } \\
\text { modulation. }\end{array}$ & $\begin{array}{ll}\text { - } & \text { LOE- IV } \\
\text { - } & \text { Rec Grade-E }\end{array}$ & $\begin{array}{l}\text { - No control, no } \\
\text { blinding. Sample } \\
\text { was small. } \\
\text { - Used a non- } \\
\text { standardised tool } \\
\text { whose validity has not } \\
\text { yet been tested. }\end{array}$ \\
\hline
\end{tabular}




\begin{tabular}{|c|c|c|c|c|c|c|}
\hline $\begin{array}{l}\text { Lloyd et al., } \\
2014 \\
\text { (Australia) }\end{array}$ & $\begin{array}{l}\text { An } \\
\text { investigation } \\
\text { into the } \\
\text { effectiveness } \\
\text { of sensory } \\
\text { modulation in } \\
\text { reducing } \\
\text { seclusion } \\
\text { within an } \\
\text { acute } \\
\text { inpatient unit }\end{array}$ & $\begin{array}{l}\text { Observatio } \\
\text { nal study } \\
\text { (case } \\
\text { control } \\
\text { /Pre-and } \\
\text { Post) }\end{array}$ & $\begin{array}{l}\text { This was a naturalist } \\
\text { study utilising } \\
\text { convenience } \\
\text { sampling. SM was } \\
\text { introduced in one } \\
\text { ward and not the } \\
\text { other. Seclusion } \\
\text { rates were compared } \\
\mathrm{n}=237 \text { male and } \\
\mathrm{n}=99 \text { female } \\
\text { patients. Feelings on } \\
\text { the Emotions Rating } \\
\text { Scale were compared } \\
\text { before and after a SM } \\
\text { intervention. } \mathrm{N}=71 \\
\text { patients }\end{array}$ & 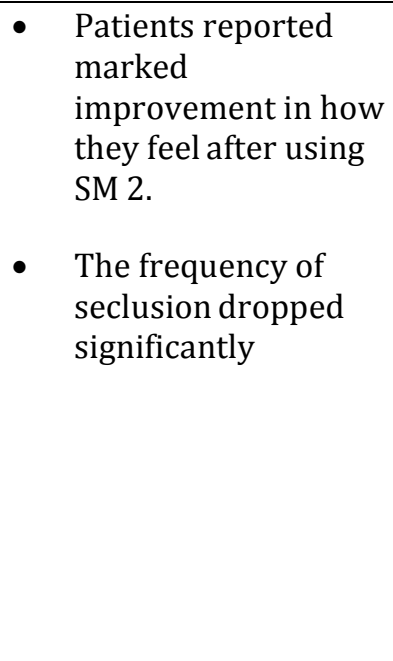 & $\begin{array}{ll}\text { - } & \text { LOE- 3-2 } \\
\text { - } & \text { Rec Grade-C }\end{array}$ & $\begin{array}{ll} & \text { No blinding; } \\
\text { - } & \text { Naturalist study with } \\
& \text { no real controls. } \\
\text { - } & \text { Patients were not } \\
& \text { randomly assigned. } \\
\text { - } & \text { Participants were not } \\
\text { categorised by } \\
\text { conditions. }\end{array}$ \\
\hline $\begin{array}{l}\text { Bar- } \\
\text { Shalita et } \\
\text { al., } 2012 \\
\text { (Israel) }\end{array}$ & $\begin{array}{l}\text { Psychophysica } \\
\text { l correlates in } \\
\text { adults with } \\
\text { sensory } \\
\text { modulation } \\
\text { disorder }\end{array}$ & $\begin{array}{l}\text { Quasi- } \\
\text { experiment } \\
\text { al study } \\
\text { with a } \\
\text { control } \\
\text { group }\end{array}$ & $\begin{array}{l}151 \text { adults ( } 68 \text { males } \\
\text { and } 83 \text { females) } \\
\text { were tested } \\
\text { comparing } 91 \text { SMD } \\
\text { to } 60 \text { SMD-free, } \\
\text { control individuals. } \\
\text { Group placement } \\
\text { (SMD vs. SMD- free) } \\
\text { was determined } \\
\text { using the Sensory } \\
\text { Responsiveness } \\
\text { Questionnaire (SRQ). }\end{array}$ & 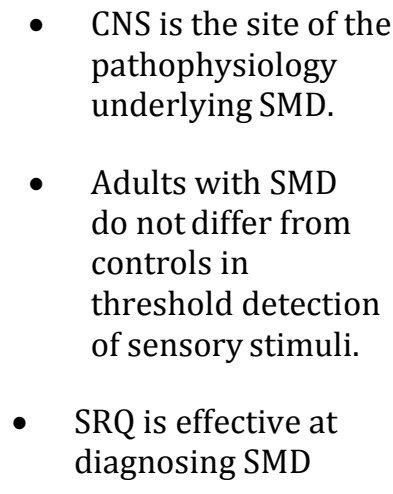 & $\begin{array}{ll}\text { - } & \text { LOE- 3-1 } \\
\text { - } & \text { Rec Grade-B }\end{array}$ & $\begin{array}{ll}\text { - } & \text { No randomisation } \\
\text { - } & \text { Participants had no } \\
\text { known } \\
\text { psychopathology but } \\
\text { testing was not done } \\
\text { to rule it out. }\end{array}$ \\
\hline
\end{tabular}




\begin{tabular}{|c|c|c|c|c|c|c|}
\hline $\begin{array}{l}\text { Olson, } \\
2010 . \\
\text { (USA) }\end{array}$ & $\begin{array}{l}\text { Examining } \\
\text { Schizophrenia } \\
\text { and Sensory } \\
\text { Modulation } \\
\text { disorder: A } \\
\text { Review of } \\
\text { literature }\end{array}$ & $\begin{array}{l}\text { literature } \\
\text { review - } \\
\text { narrative } \\
\text { approach }\end{array}$ & $\begin{array}{l}\text { Literature review - } \\
\text { narrative approach }\end{array}$ & $\begin{array}{l}\text { Concluded that there } \\
\text { is preliminary support } \\
\text { for the relationship } \\
\text { between } \\
\text { schizophrenia and } \\
\text { SMD. }\end{array}$ & $\begin{array}{ll}\text { - } & \text { RF-QRA } \\
& \text { Level } 4 . \\
& \\
\text { - } & \text { Rec Grade D }\end{array}$ & $\begin{array}{l}\text { Narrative literature } \\
\text { review which does not } \\
\text { involve observation. }\end{array}$ \\
\hline $\begin{array}{l}\text { Olson, } \\
2011 . \\
\text { (USA) }\end{array}$ & $\begin{array}{l}\text { Sensory } \\
\text { modulation } \\
\text { disorder and } \\
\text { schizophrenia: } \\
\text { linking } \\
\text { behavioural } \\
\text { measures., } \\
\text { PhD } \\
\text { dissertation }\end{array}$ & $\begin{array}{l}\text { A cross- } \\
\text { sectional } \\
\text { design }\end{array}$ & $\begin{array}{l}\text { A cross-sectional design } \\
\text { using convenience } \\
\text { sampling Multi-site testing } \\
\text { using the Positive and } \\
\text { Negative Syndrome Scale } \\
\text { (PANSS) and the } \\
\text { Adolescent/Adult Sensory } \\
\text { Profile (A/ASP) was used }\end{array}$ & $\begin{array}{l}\text { positive relationship } \\
\text { between positive } \\
\text { symptoms of } \\
\text { schizophrenia and } \\
\text { the low registration } \\
\text { and sensory } \\
\text { sensitivity } \\
\text { quadrants of the } \\
\text { A/ASP. } \\
\text { - No significant } \\
\text { relationships were } \\
\text { found between } \\
\text { negative symptoms } \\
\text { and patterns of } \\
\text { SMD. }\end{array}$ & $\begin{array}{ll}\text { - } & \text { LOE- 3-2 } \\
\text { - } & \text { Rec Grade- } \\
& \mathrm{C}\end{array}$ & $\begin{array}{l}\text { - The study was } \\
\text { under-powered - } \\
40 \text { subjects } \\
\text { - Type } 1 \text { error due } \\
\text { to use of } \\
\text { numerous } \\
\text { statistical } \\
\text { analyses } \\
\text { - Selection bias due } \\
\text { to convenience } \\
\text { sampling }\end{array}$ \\
\hline
\end{tabular}




\begin{tabular}{|c|c|c|c|c|c|c|}
\hline $\begin{array}{l}\text { Champagne, T } \\
\text { and Frederick, } \\
\text { D. } 2011 . \\
\text { (USA) }\end{array}$ & $\begin{array}{l}\text { Sensory } \\
\text { processing } \\
\text { research } \\
\text { advances in } \\
\text { mental health - } \\
\text { implications } \\
\text { for } \\
\text { occupational } \\
\text { therapy }\end{array}$ & $\begin{array}{l}\text { Literatur } \\
\text { e review - } \\
\text { narrative } \\
\text { approach }\end{array}$ & $\begin{array}{l}\text { Literature review- } \\
\text { narrative approach }\end{array}$ & $\begin{array}{l}\text { More translational } \\
\text { research is needed }\end{array}$ & $\begin{array}{ll}- & \text { RF-QR } \\
& \text { Level } 4 . \\
& \text { Rec } \\
\text { Grade- E }\end{array}$ & $\begin{array}{l}\text { Not research-literature } \\
\text { review -narrative } \\
\text { approach. }\end{array}$ \\
\hline $\begin{array}{l}\text { Novak et al, } \\
2012 . \\
\text { (Australia) }\end{array}$ & $\begin{array}{l}\text { Pilot study of a } \\
\text { sensory room } \\
\text { in an acute } \\
\text { inpatient unit }\end{array}$ & $\begin{array}{l}\text { Pre-and } \\
\text { Post with } \\
\text { no control }\end{array}$ & $\begin{array}{l}\text { Naturalist study- } \\
\text { Consumers rated distress } \\
\text { and staff rated observed } \\
\text { disturbed behaviour } \\
\text { before and after use of } \\
\text { sensory room. Sample } \\
\text { size for participants with } \\
\text { schizophrenia <20. }\end{array}$ & $\begin{array}{l}\text { Use of the sensory } \\
\text { room reduced } \\
\text { distress but had no } \\
\text { effect on seclusion } \\
\text { rates. } \\
\text { Weighted blankets } \\
\text { were found to be } \\
\text { useful. }\end{array}$ & $\begin{array}{ll}- & \text { LOE- 3-3 } \\
\text { - } & \text { Rec } \\
& \text { Grade-D }\end{array}$ & $\begin{array}{ll}\text { - } & \text { No randomization } \\
\text { - } & \text { No blinding } \\
\text { - } & \text { No controls of } \\
& \text { unstandardized } \\
& \text { tools } \\
\text { - } & \text { Sample size } \\
& \text { relatively small }\end{array}$ \\
\hline $\begin{array}{l}\text { Champagne, T } \\
\text { and Koomar, J., } \\
2012 \\
\text { (USA) }\end{array}$ & $\begin{array}{l}\text { Evaluating } \\
\text { sensory } \\
\text { processing in } \\
\text { mental health } \\
\text { occupational } \\
\text { therapy } \\
\text { practice }\end{array}$ & $\begin{array}{l}\text { Literature } \\
\text { review - } \\
\text { narrative } \\
\text { approach }\end{array}$ & $\begin{array}{l}\text { literature review - } \\
\text { narrative approach }\end{array}$ & $\begin{array}{l}\text { Recommends more } \\
\text { comprehensive } \\
\text { assessment in OT } \\
\text { that includes } \\
\text { sensory processing } \\
\text { patterns }\end{array}$ & $\begin{array}{ll} & \text { RF-QRA } \\
& \text { Level } 4 . \\
& \\
\text { - } & \text { Grade of } \\
\text { recommen } \\
\text { dation - } \\
\text { Grade E }\end{array}$ & $\begin{array}{ll}\text { - } & \text { Not research. } \\
\text { - } & \text { Literature review - } \\
& \text { narrative approach. }\end{array}$ \\
\hline $\begin{array}{l}\text { Kinnealey et al., } \\
2011 . \\
\text { (USA) }\end{array}$ & $\begin{array}{l}\text { Relationships } \\
\text { between } \\
\text { Sensory } \\
\text { modulation and } \\
\text { social supports } \\
\text { and health } \\
\text { related quality } \\
\text { of life }\end{array}$ & $\begin{array}{l}\text { Quasi- } \\
\text { experimen } \\
\text { tal with no } \\
\text { control } \\
\text { group }\end{array}$ & $\begin{array}{l}28 \text { participants -14 SOR } \\
\text { and 14 NSOR. All } \\
\text { participants were tested } \\
\text { using self-administered } \\
\text { measures. Tools used } \\
\text { were; Adult Sensory } \\
\text { Questionnaire; MOS; } \\
\text { Beck's Anxiety Index; } \\
\text { Beck's Depression } \\
\text { Inventory. }\end{array}$ & $\begin{array}{ll}\text { - } & \text { Sensory style is } \\
\text { related to symptoms } \\
\text { of affective mental } \\
\text { health and quality of } \\
\text { life indicators. }\end{array}$ & $\begin{array}{ll}- & \text { LOE- 3-2 } \\
\text { - } & \text { Rec } \\
& \text { Grade-C }\end{array}$ & $\begin{array}{ll}\text { - } & \text { Subjects not } \\
& \text { randomised. } \\
\text { - } & \text { Small sample }<20 . \\
\text { - } & \text { No control group. } \\
& \text { Only healthy } \\
& \text { subjects used. }\end{array}$ \\
\hline
\end{tabular}




\begin{tabular}{|c|c|c|c|c|c|c|}
\hline $\begin{array}{l}\text { Champagne, T } \\
\text { and Koomar, J. } \\
2011 . \\
\text { (USA) }\end{array}$ & $\begin{array}{l}\text { Expanding the } \\
\text { focus: } \\
\text { Addressing } \\
\text { sensory } \\
\text { discrimination } \\
\text { concerns in } \\
\text { mental health }\end{array}$ & $\begin{array}{l}\text { Narrative } \\
\text { literature } \\
\text { review }\end{array}$ & $\begin{array}{l}\text { review and opinion } \\
\text { piece published by } \\
\text { AOTA }\end{array}$ & 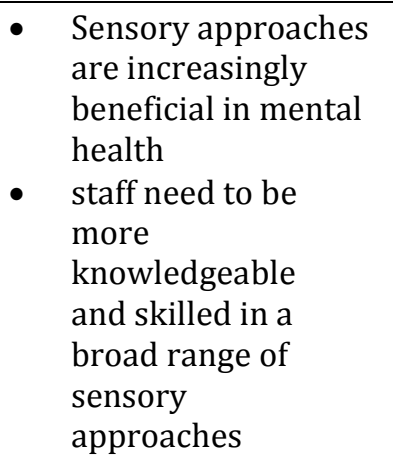 & $\begin{array}{ll}- & \text { RF-QRA } \\
& \text { Level } 4 . \\
& \\
& \text { Grade of } \\
& \text { recommen } \\
\text { dation - } \\
\text { Grade E }\end{array}$ & $\begin{array}{ll} & \text { Not Research- } \\
& \text { Literature review }\end{array}$ \\
\hline $\begin{array}{l}\text { Brown et al., } \\
2002 \\
\text { (USA) }\end{array}$ & $\begin{array}{l}\text { Sensory } \\
\text { processing in } \\
\text { schizophrenia: } \\
\text { Missing and } \\
\text { avoiding } \\
\text { information. }\end{array}$ & $\begin{array}{l}\text { Observation } \\
\text { al study } \\
\text { (case control } \\
\text { study) }\end{array}$ & $\begin{array}{l}\text { Examined the presence of } \\
\text { SMD in persons with } \\
\text { schizophrenia using the A/ } \\
\text { ASP }\end{array}$ & $\begin{array}{ll}\text { - } & \text { Adults with } \\
\text { schizophrenia } \\
\text { (Sz) demonstrate } \\
\text { SMD. } \\
\text { - Sz had higher scores } \\
\text { in; sensory avoiding } \\
\text { \& low registration } \\
\text { and lower in: } \\
\text { sensation seeking. }\end{array}$ & $\begin{array}{ll}\text { - } & \text { LOE- 3-2 } \\
\text { - } & \text { Rec } \\
& \text { Grade-C }\end{array}$ & $\begin{array}{l}\text { No consideration } \\
\text { of phase of illness. }\end{array}$ \\
\hline $\begin{array}{l}\text { Pfeiffer, B and } \\
\text { Kinnealey, } \\
2003 . \\
\text { (USA) }\end{array}$ & $\begin{array}{l}\text { Treatment of } \\
\text { sensory } \\
\text { defensiveness } \\
\text { in adults }\end{array}$ & $\begin{array}{l}\text { Pre- test } \\
\text { and post- } \\
\text { test }\end{array}$ & $\begin{array}{l}\text { Examined the relationship } \\
\text { between sensory } \\
\text { defensiveness and anxiety } \\
\text { using the Adult Sensory } \\
\text { Questionnaire, Adult } \\
\text { Sensory Interview, } \\
\text { and Beck's Anxiety Index. } \\
15 \text { Participants were } \\
\text { involved. }\end{array}$ & $\begin{array}{l}\text { Significant } \\
\text { relationship was } \\
\text { found between } \\
\text { sensory } \\
\text { defensiveness and } \\
\text { anxiety and } \\
\text { following an } \\
\text { intervention } \\
\text { designed for people } \\
\text { with SMD both } \\
\text { conditions } \\
\text { significantly } \\
\text { decreased. }\end{array}$ & $\begin{array}{ll}- & \text { LOE-3-2 } \\
- & \text { Rec Grade- } \\
& \text { C }\end{array}$ & $\begin{array}{l}\text { - Small sample } \\
\text { size was used. } \\
\text { No control } \\
\text { group used. }\end{array}$ \\
\hline
\end{tabular}


EFFECTIVENESS OF SENSORY MODULATION

\begin{tabular}{|c|c|c|c|c|c|c|}
\hline $\begin{array}{l}\text { Bar- Shalita, } \\
\text { et al.,2014 } \\
\text { (Israel) }\end{array}$ & $\begin{array}{l}\text { Atypical } \\
\text { central pain } \\
\text { processing in } \\
\text { sensory } \\
\text { modulation } \\
\text { disorder: }\end{array}$ & $\begin{array}{l}\text { Quasi- } \\
\text { experiment } \\
\text { al study } \\
\text { with a } \\
\text { control } \\
\text { group }\end{array}$ & $\begin{array}{l}\text { Twelve SOR adults and } 12 \\
\text { healthy controls } \\
\text { participated. TS was } \\
\text { produced by a train of } \\
\text { fifteen repetitive heat } \\
\text { pulses, No TS of pain was } \\
\text { indicated in the SOR group } \\
\text { (SOR: } p=0.36 \text {; control: } \mathrm{p}< \\
0.001 \text { ). }\end{array}$ & $\begin{array}{l}\text { These results } \\
\text { demonstrate an } \\
\text { atypical } \\
\text { response } \\
\text { pattern, } \\
\text { suggesting } \\
\text { alteration in } \\
\text { pain processing } \\
\text { and/or } \\
\text { modulation at a } \\
\text { central level in } \\
\text { individuals with } \\
\text { SOR. }\end{array}$ & $\begin{array}{l}\text { - } \quad \text { LOE- 3-1 } \\
\text { - } \quad \text { Rec Grade-B }\end{array}$ & $\begin{array}{ll}\text { - } & \text { No } \\
\text { - } & \text { randomization } \\
& \text { Sample small } \\
\text { participants not } & \text { fully described. } \\
\text { - } & \text { Temporality } \\
\text { differences } \\
\text { during } \\
\text { measurement } \\
\text { throughout the } \\
\text { day. Appears as } \\
\text { if only healthy } \\
\text { subjects used. }\end{array}$ \\
\hline $\begin{array}{l}\text { Sutton } \\
\text { et al., } \\
2013 \\
\text { (New } \\
\text { Zealand) }\end{array}$ & $\begin{array}{l}\text { Optimizing } \\
\text { arousal to } \\
\text { manage } \\
\text { aggression: A } \\
\text { pilot study of } \\
\text { sensory } \\
\text { modulation. }\end{array}$ & $\begin{array}{l}\text { Qualitative } \\
\text { inductive } \\
\text { approach }\end{array}$ & $\begin{array}{l}\text { A pilot trial of sensory- } \\
\text { based interventions in four } \\
\text { inpatient mental health } \\
\text { units in New Zealand. } \\
\quad \text { Themes }\end{array}$ & $\begin{array}{l}\text { Modifications to the } \\
\text { environment and the use } \\
\text { of soothing stimuli } \\
\text { moderate or optimize } \\
\text { arousal and promote an } \\
\text { ability to adaptively } \\
\text { regulate emotion }\end{array}$ & $\begin{array}{ll}- & \text { RF-QRA } \\
& \text { Level } 3 . \\
& \text { Grade of } \\
\text { recommen } \\
\text { dation - } \\
\text { Grade D }\end{array}$ & $\begin{array}{l}\text { - Characteristics of } \\
\text { the participants } \\
\text { not explained. } \\
\text { - No randomisation. }\end{array}$ \\
\hline $\begin{array}{l}\text { Champagne \& } \\
\text { Stromberg, } \\
2004 \\
\text { (USA) }\end{array}$ & $\begin{array}{l}\text { Sensory } \\
\text { approaches in } \\
\text { inpatient } \\
\text { psychiatric } \\
\text { settings; } \\
\text { innovative } \\
\text { alternatives to } \\
\text { seclusion \& } \\
\text { restraint }\end{array}$ & $\begin{array}{l}\text { Literature } \\
\text { Review } \\
\text {-narrative } \\
\text { approach }\end{array}$ & $\begin{array}{l}\text { Authors' reflect on their } \\
\text { experience and refer to the } \\
\text { literature. }\end{array}$ & 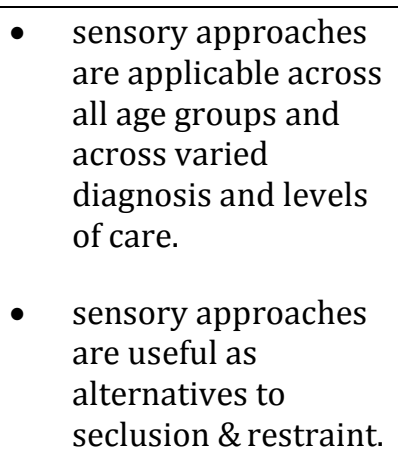 & $\begin{array}{ll}- & \text { RF-QRA } \\
& \text { Level } 4 . \\
& \text { Grade of } \\
\text { recommen } \\
\text { dation - } \\
\text { Grade E }\end{array}$ & $\begin{array}{ll}\text { - } & \text { Not research. } \\
\text { Narrative } \\
\text { literature review } \\
\text { and authors' } \\
\text { expert/ } \\
\text { professional } \\
\text { opinions presented } \\
\text { which limits } \\
\text { validity of results. }\end{array}$ \\
\hline
\end{tabular}




\begin{tabular}{|c|c|c|c|c|c|c|}
\hline $\begin{array}{l}\text { Van Pomeren, } \\
2009 \\
\text { (New } \\
\text { Zealand) }\end{array}$ & $\begin{array}{l}\text { Sensory } \\
\text { Modulation: } \\
\text { one approach } \\
\text { to reducing } \\
\text { the use of } \\
\text { seclusion and } \\
\text { restraint at }\end{array}$ & Narrative & $\begin{array}{l}\text { Description of } \\
\text { implementation of } \\
\text { SM }\end{array}$ & $\begin{array}{l}\text { - } \\
\text { Reduction in } \\
\text { seclusion is } \\
\text { reported following } \\
\text { implementation of a } \\
\text { sensory room. } \\
\text { - Anecdotal } \\
\text { evidence } \\
\text { referred to. }\end{array}$ & $\begin{array}{ll}- & \text { RF-QRA } \\
\text { level 5, } \\
\text { - } & \text { Grade of } \\
\text { recommend } \\
\text { ation E }\end{array}$ & $\begin{array}{ll}- & \text { Narrative } \\
\text { approach. } \\
\text { - } \\
\text { Results cannot be } \\
\text { generalized. }\end{array}$ \\
\hline
\end{tabular}

\begin{tabular}{|c|c|c|c|c|c|c|}
\hline $\begin{array}{l}\text { Smith \& } \\
\text { Jones., } 2014 \\
\text { (USA) }\end{array}$ & $\begin{array}{l}\text { Sensory Room } \\
\text { on an } \\
\text { intensive care } \\
\text { Unit }\end{array}$ & $\begin{array}{l}\text { Mixed } \\
\text { Method } \\
\text { research }\end{array}$ & \begin{tabular}{l}
\multicolumn{1}{c}{ A mixed method } \\
research design was used, \\
with the collection of \\
seclusion data before and \\
after a sensory room was \\
introduced followed by \\
qualitative interviews with \\
staff and patients.
\end{tabular} & $\begin{array}{l}\text { - } \\
\text { reduction in } \\
\text { seclusion rates was } \\
\text { noted with the } \\
\text { introduction of the } \\
\text { seclusion room. } \\
\text { However, the } \\
\text { interviews } \\
\text { revealed a } \\
\text { perception among } \\
\text { staff that there had } \\
\text { been a reduction in } \\
\text { seclusion rates. }\end{array}$ & $\begin{array}{ll}\text { - } & \text { LOE- 3- } \\
3 & \\
\text { - } & \text { Rec } \\
& \text { Grade- } \\
\text { D }\end{array}$ & $\begin{array}{ll}\text { - } & \text { Small sample. } \\
\text { - } & \text { No randomization, }\end{array}$ \\
\hline $\begin{array}{l}\text { Lee et al, } 2010 \\
\text { (Australia) }\end{array}$ & $\begin{array}{l}\text { Sensory } \\
\text { assessment } \\
\text { and therapy to } \\
\text { help reduce } \\
\text { seclusion use } \\
\text { with service } \\
\text { users needing } \\
\text { psychiatric } \\
\text { intensive care }\end{array}$ & A pilot study & $\begin{array}{l}\text { A six-month pilot of the } \\
\text { use of sensory modulation } \\
\text { strategies and a brief } \\
\text { sensory and risk } \\
\text { assessment tool (Safety } \\
\text { Tool) was implemented on } \\
\text { a 30-bed acute psychiatric } \\
\text { unit. }\end{array}$ & 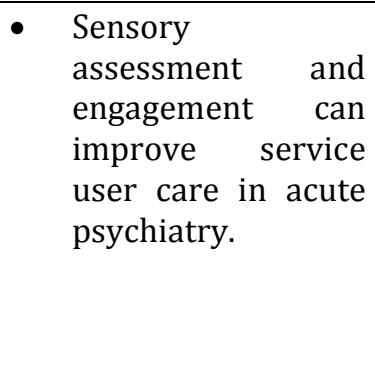 & $\begin{array}{ll} & \text { LOE- 3- } \\
3 & \\
\text { - } & \text { Rec } \\
& \text { Grade- } \\
\text { D }\end{array}$ & $\begin{array}{l}\text { - Safety Tool used } \\
\text { was not a } \\
\text { standardised tool. } \\
\text { Sample too small } \\
\text { - } \quad \text { No randomization }\end{array}$ \\
\hline
\end{tabular}




\begin{tabular}{|c|c|c|c|c|c|c|}
\hline $\begin{array}{l}\text { Champagne, T } \\
\text { and Sayer, E., } \\
2009 \\
\text { (USA) }\end{array}$ & $\begin{array}{l}\text { The effects of } \\
\text { a sensory } \\
\text { room }\end{array}$ & $\begin{array}{l}\text { Pre-and } \\
\text { Post - } \\
\text { quality } \\
\text { improve } \\
\text { ment } \\
\text { study }\end{array}$ & $\begin{array}{l}\text { Quality improvement study on } \\
\text { the use of the multi- sensory } \\
\text { room on an in-patient } \\
\text { psychiatric unit, with } \\
\text { adolescent and adult clients } \\
\text { A sample size of forty-seven } \\
\text { clients ranging in age from } 17 \\
\text { to } 93 \text { years randomly } \\
\text { participated in this study. } \\
\text { Diagnosis mixed -26 different } \\
\text { types. Used a pre-and post } \\
\text { tool as well as ACLS }\end{array}$ & $\begin{array}{l}\text { - Sensory room had } \\
\text { positive effects on } \\
\text { participants }\end{array}$ & $\begin{array}{ll}- & \text { LOE- } \\
& 3-3 \\
-\quad & \text { Rec } \\
\text { Grade- } & \text { D }\end{array}$ & $\begin{array}{ll} & \text { Convenience sampling- } \\
\text { bias } \\
\text { - } & \text { Used a non } \\
& \text { standardised tool }\end{array}$ \\
\hline $\begin{array}{l}\text { Mullen, } \\
\text { Champagne, } \\
\text { Krishnamurth } \\
\text { y, Dickson , \& } \\
\text { Gao.,2008. } \\
\text { (USA) }\end{array}$ & $\begin{array}{l}\text { Exploring the } \\
\text { Safety and } \\
\text { Therapeutic } \\
\text { Effects of Deep } \\
\text { Pressure } \\
\text { Stimulation } \\
\text { Using a } \\
\text { Weighted } \\
\text { Blanket }\end{array}$ & $\begin{array}{l}\text { Mixed } \\
\text { methods } \\
- \\
\text { Experim } \\
\text { ental } \\
\text { design }\end{array}$ & $\begin{array}{l}\text { The qualitative data gathering } \\
\text { process was embedded within } \\
\text { the quantitative procedures. } \\
\text { The final sample size of the } \\
\text { study was } n=32 \text {, Healthy } \\
\text { individuals with no apparent } \\
\text { medical, or physical conditions. }\end{array}$ & $\begin{array}{l}\text { - } 33 \% \text { demonstrated } \\
\text { lowering in EDA } \\
\text { when using the } \\
\text { weighted blanket, } \\
63 \% \text { reported lower } \\
\text { anxiety after use, and } \\
78 \% \text { preferred the } \\
\text { weighted blanket as } \\
\text { a calming modality. } \\
\text { the use of a } 30 \mathrm{lb} \\
\text { weighted blanket did } \\
\text { not adversely } \\
\text { influence pulse } \\
\text { oximetry, pulse rate, } \\
\text { or blood pressure. }\end{array}$ & $\begin{array}{ll}\text { - } & \text { III-2 } \\
\text { - } & \text { Grade D }\end{array}$ & $\begin{array}{ll}\text { - } & \text { Convenience } \\
\text { sample Under- } \\
\text { powered }(\mathrm{n}+32) \\
\text { Results cannot be } \\
\text { generalized to the use } \\
\text { of the } 30 \mathrm{lb} \text { weighted } \\
\text { blanket for longer time } \\
\text { periods. } \\
\text { Use of healthy } \\
\text { subjects is not } \\
\text { representative of } \\
\text { people with other } \\
\text { disorders }\end{array}$ \\
\hline
\end{tabular}


Figure 1: Geographical Distribution of Studies

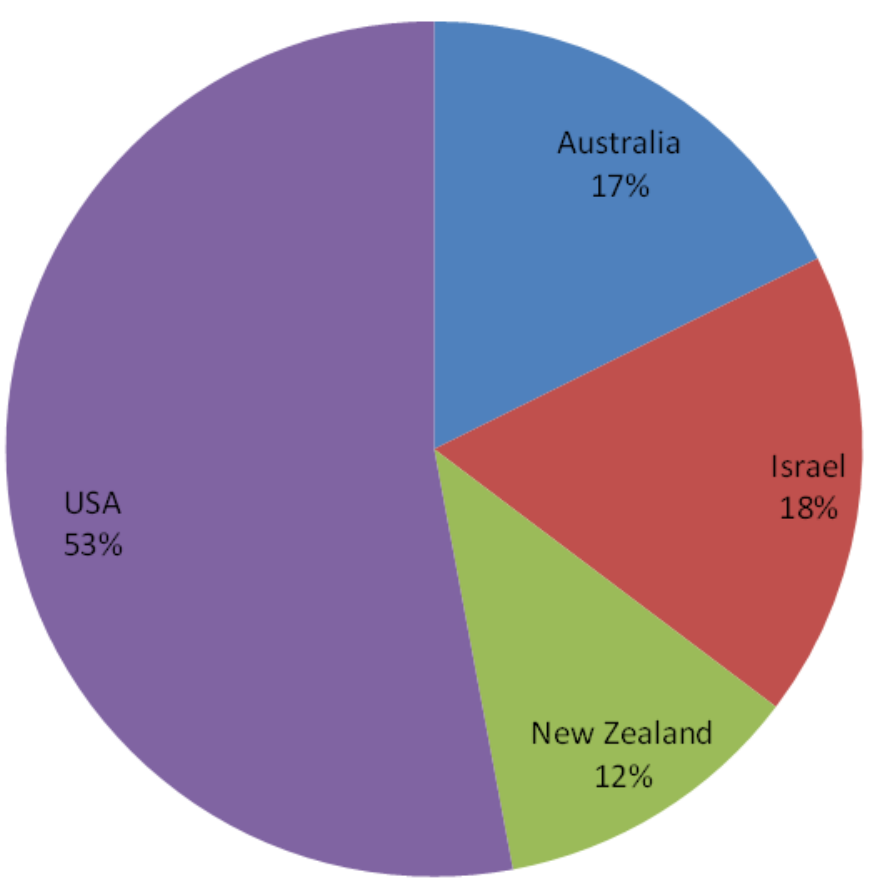

